\title{
JOURNAL.RU
}

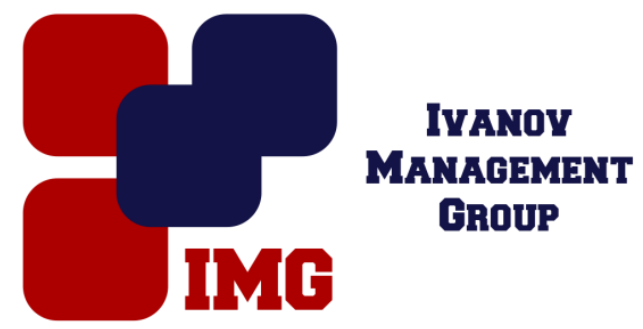

Елькина Н.А.

Петрозаводский государственньй университет Петрозаводск, Россия

doi: $10.18411 / 1 \mathrm{j}-31-07-2017-31$

idsp 000001:1j-31-07-2017-31

\section{Оценка адаптивного потенциала генеративной сферы Alopecurus arundinaceus Poir., произрастающего на приливно-отливной зоне Белого моря}

\section{Аннотация}

Ведется поиск растений приливно-отливной зоны Белого моря с высоким адаптивным потенциалом генеративной сферы. Изучены морфологические характеристики пыльцевых зерен Лисохвоста тростниковидного (Alopecurus arundinaceus Poir.). Установлено количество нормально сформированной и дефектной пыльцы лисохвоста, типы аномалий развития пыльцевых зерен. Адаптивный потенциал генеративной сферы лисохвоста невысок, данный вид не может быть рекомендован для дальнейшего изучения как возможного видаиндикатора экологического состояния приливно-отливной зоны Белого моря.

Ключевые слова. Адаптивный потенциал, приливно-отливная зона, Белое море, пыльцевые зерна, аномалии развития пыльцы.

Продолжено изучение генеративной сферы различных растений, произрастающих в условиях приливно-отливной зоны Белого моря, начатое сотрудниками и студентами кафедры ботаники и физиологии растений Петрозаводского государственного университета в 2012 году (Сонина, Елькина, Марковская, 2013; Елькина, Карпова, 2015а; Елькина, Карпова, 2015б; Елькина, Карпова, 2016).

Объект настоящего исследования - Лисохвост тростниковидный (Alopecurus arundinaceus Poir., сем. Роасеаe) - рыхлодерновинное многолетнее 
растение с ползучими побегами, серовато-зелёное, 50-120 см высотой. Листья 35 мм шириной. Соцветия 5-10 см длиной, бледно-зелёные, при созревании плодов чернеющие. Колоски густоволосистые, около 4 мм длиной. Пыльники 2-3 мм. Цветёт в июне, плодоношение наступает в июле. Данный вид характерен для приморских лугов, встречается на солончаках, на травяных болотах. Размножается и распространяется как семенами, так и вегетативно (Марковская и др., 2010).

Пыльцевые зерна лисохвоста однопоровые, эллиптические, с экватора шаровидные, с полюса овальные. Наибольший диаметр варьирует в пределах 25-70 мкм. Пора округлая с ободком. Скульптура поверхности пыльцевого зерна волнистая, хорошо заметна. Спородерма состоит из экзины, в которой выделяется покров, столбики и подстилающий слой, и интины, сильно утолщенной в области поры (Пунсалмапуу и др., 2012).

Для изучения особенностей морфологического строения пыльцы собраны соцветия растений лисохвоста на пробных площадках трансект и зафиксированы в 70\% спирте. Образец пробной площадки составляли из соцветий 3-4 растущих рядом хорошо развитых растений.

Качество пыльцевых зерен оценивали стандартным ацетокарминовым методом (Паушева, 1980), который позволяет описать и оценить морфологические характеристики как нормально развитых пыльцевых зерен, так и дефектных. Нормально развитой считается пыльца, содержащая вегетативную клетку с розовой (карминной) равномерно окрашенной зернистой цитоплазмой, с вегетативным ядром и генеративной клеткой с 2 спермиями. К дефектной или стерильной относят пыльцу с окрашенной кармином неравномерно или неокрашенной цитоплазмой, а так же сморщенные зерна и др. Часто цитоплазма отходит от оболочки и находится на разных стадиях деструкции.

Пыльцевой материал для изучения морфологических характеристик собран в июле 2014 г. на берегу Кандалакшского залива Белого моря в устье р.

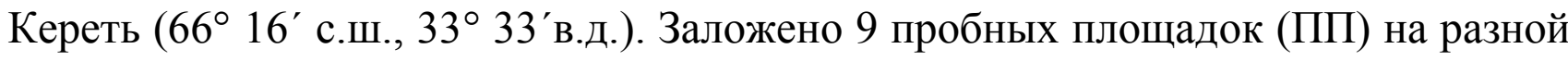
удаленности от уреза воды, и характеризующихся разным временем заливания, типом субстрата и т.д. Литоральная зона трансекты (большинство ПП) подвергается заливанию на 6-8 ч с четкой периодичностью. На ПП, расположенных на супралиторали - в зоне заплеска (брызг) изредка заливанию подвергается корневая система растений.

Растения лисохвоста тростниковидного были зафиксированы только на двух из девяти ПП, находящихся в зоне супралиторали и не подвергающихся 
полному заливанию морской водой. Количество нормально сформированной пыльцы практически одинаково и составляет 63-66\%. Значения коэффициента вариации (CV) составило 9,8-10,6\%.

Помимо нормально развитых в пробах обнаружены пыльцевые зерна с различными дефектами развития. Чаще всего встречаются пыльцевые зерна без содержимого $(15,4-18,3 \%)$. При этом скульптура экзины нормально развита и сохранена форма пыльцевого зерна. Однако пыльца не окрашивается кармином. Реже встречаются нарушения, связанные с состоянием цитоплазмы вегетативной клетки пыльцевого зерна $(9,6-12,4 \%)$. Цитоплазма отходит от оболочек и выглядит комковатой, неравномерно прокрашена ацетокармином. Патологическая вакуолизация цитоплазмы - самый редкий дефект развития пыльцы лисохвоста (5,7-8,3\%). Такое пыльцевое зерно сохраняет свою форму и размер, а цитоплазма выглядит вспененной.

Полученные результаты показали, что вдоль трансекты по направлению от литорали к супралиторали незначительно увеличивается количество пыльцы лисохвоста без содержимого (с 15,4 до 18,3\%), уменьшается количество пыльцевых зерен со скомканной цитоплазмой (с 12,4 до 9,6\%). Возможно, длительный контакт с соленой водой приводит к плазмолизу вегетативной клетки пыльцы. Количество пыльцы с патологической вакуолизацией цитоплазмы также уменьшается по мере удаления от уреза воды, вероятно, это также связано с влиянием морской воды.

Изучение морфологических характеристик пыльцы лисохвоста, произрастающего в устье р. Кереть было продолжено в июле 2016 г. Для сбора пыльцевого материала были заложены две трансекты в направлении с севера на юг. Большая часть пробных площадок располагалась в литоральной зоне, остальные - в зоне супралиторали, там, где растения не заливаются во время приливов полностью.

На обеих трансектах растения лисохвоста, были зафиксированы только на одной ПП, на супралиторали. Количество нормально сформированной пыльцы составило 59,5-62 \%. CV составил 14-16\% - средний уровень варьирования.

Как и в 2014 г. дефекты в развитии пыльцы лисохвоста чаще всего представлены пустыми пыльцевыми зернами (21,4-23\%), с сохранением размеров и формы пыльцы и скульптуры поверхности. Комковатая цитоплазма вегетативной клетки встречается вдвое реже $(6,0-10,8 \%)$. Наиболее редкая аномалия - патологическая вакуолизация цитоплазмы $(7,8-8,3 \%)$. 
Наиболее благоприятные условия для роста и развития растений лисохвоста тростниковидного на приливно-отливной полосе Белого моря - зона супралиторали с каменисто-песчаным субстратом. На территориях, подвергающихся большему влиянию приливно-отливной волны, с более длительным заливанием, лисохвост тростниковидный обнаружен нами не был.

Согласно литературным данным, пыльцу со степенью дефектности свыше $11 \%$ следует считать дефектной, а вид растения - склонным к апомиксису (Куприянов, Жолобова, 1975). У изученного нами вида растения степень дефектности значительно превышает граничные значения и составляет 34-40 \%, что позволяет сделать вывод о крайне невысоком генеративном потенциале лисохвоста тростниковидного в условиях приливно-отливной зоны Белого моря. Вероятнее всего, размножение растений осуществляется в основном вегетативным путем. Лисохвост тростниковидный не может быть рекомендован к использованию в качестве вида-индикатора состояния приливно-отливной зоны северных морей с помощью палиноиндикационного метода.

$$
* * *
$$

1. Елькина, Н.А., Карпова Е.Е. Применение палиноиндикационного метода для оценки адаптивного потенциала приморских растений западного побережья Белого моря // Ученые записки Петрозаводского государственного университета. - Петрозаводск : ПетрГУ, 2015а. - №8 (25). - С.52-56.

2. Елькина, Н.А., Карпова Е.Е. Возможности применения палиноиндикационного метода для исследования состояния окружающей среды // Сборник материалов 5 Международной научно-практической конференции Евразийского Научного Объединения "Стратегии устойчивого развития мировой науки". - Москва : Евразийское научное Объединение (ЕНО), 2015б. - С.34-36.

3. Елькина, Н.А., Карпова Е.Е. применение палиноиндикационного метода для оценки адаптивного потенциала некоторых растений побережья Белого моря // Сборник научных трудов по материалам научно-практической конференции "Научный диалог: Молодой ученый". - Самара, ЦНК МНИФ "Общественная наука", 2016. - С.5-8.

4. Куприянов П.Г., Жолобова В.Г. Уточнение понятий нормальная и дефектная пыльца в антморфологическом методе // Апомиксис и цитоэмбриология растений. Саратов : Изд-во Сарат. Ун-та, 1975. Вып. 3 С. 45-52.

5. Марковская Е.Ф., Сергиенко Л.А., Шкляревич Г.А., Сонина А.В., Стародубцева А.А., Смолькова О.В. Природный комплекс побережий Белого моря. Петрозаводск: Изд-во КарНЦ РАН, 2010. 84c.

6. Паушева, 3. П. Практикум по цитологии растений. Москва : Агропромиздат, 1980. 304 с.

7. Пунсалмапуу Г., Гэгээнсувдц Ц., Менхзул Т., Золбаяр Д., Сайндовдон Д., Сангидорж Б. Морфологические особенности пыльцевых зерен некоторых родов злаковых (Роасеае Barnhart) // Вестник Бурятского государственного университета,2012. С. 255 - 258.

8. Сонина А.В., Елькина Н.А., Марковская Е.Ф. Оценка состояния пыльцевых зерен растений приливно-отливной зоны побережья Белого моря // Ученые записки ПетрГУ. Петрозаводск: Изд-во ПетрГУ, 2013. С. 7-11. 